輸入アサリに混入して移入する生物一食害生物サキグロタマッメタと 非意図的移入種

\title{
Alien Species Introduced with Imported Clams: the Clam-eating Moon Snail Euspira fortunei and Other Unintentionally Introduced Species
}

\author{
大越健嗣 \\ 石巻専修大学理工学部. $=$ 986-8580 石巻市南境新水戸 1
}

\section{Kenji OKOSHI}

Department of Biotechnology, Ishinomaki Senshu University. 1 Shinmito, Minamisakai, Ishinomaki, Miyagi 986-8580, Japan

\begin{abstract}
The clam Ruditapes philippinarum is a commercially important fishery resource in Japan. Because the amount of production has been decreasing gradually in Japan, the clam has been imported from China and Korea in recent years to provide seed for aquaculture and also for recreational shellfish gathering. The object of this study is to confirm whether alien species are being introduced together with the clam and to obtain information on their distribution in Japanese waters. Three species of mollusk-eating moon snail, Euspira fortunei, Glossaulax didyma, and Glossaulax reiniana, were collected from sacks filled with $R$. philippinarum imported from China. Seven other gastropod species, nine species of bivalves including Meretrix pethechialis, the purse crab Philyra pisum, and a brachiopod, Lingula unguis, were also collected from the sacks. Almost all the unintentionally introduced animals were living and were directly released with commercially introduced clams into Mangoku-ura Inlet, Miyagi Prefecture, by a fishermen's cooperative. Although the snail Euspira fortunei is not indigenous to the eastern and northern coasts of Japan, relatively large populations of it occur in the clam production areas of Lake Hamana (Shizuoka), the estuary of the Obitsu River (Chiba), and Mangoku-ura Inlet. I believe that a population of this invasive snail has already been established at least in Mangoku-ura Inlet and is becoming a new, strong predator of the clam stocks. Prevention of further spread and estimation of the rate of predation are important to the clam culture. Among the 22 alien species recorded in this survey, seven were also found in the native communities. The effect of the alien population on the preexisting population is also important problem to be solved.
\end{abstract}

Key Words: alien species, Euspira fortunei, predator, Ruditapes philippinarum, unintentional introduction.

\section{はじめに}

人為的にある生物を移動させると，それに伴って非意図 的に他の生物を一緒に移動させてしまうということがしば しば起こる. 大型動物の寄生虫, 体表や毛についた植物の 種子などがそうである，移動先の環境が好適であれば，そ れらは生き残り子孫を残す。そして, 移動先に定着し生態 系を徐々に，あるいは急激に変化させる場合がある。これ ら「移入種」は主に人間の産業活動がもたらしたものだが, 近年その影響が世界各地でさまざまな場面で現れている.

水産の分野でも「移入種」問題は古くて新しい問題であ る.わが国のマガキ Crassostrea gigas の種苗が初めて北米 に移植されたのは1905 年という（荒川 1985）から, 水産に おける移入種問題は 1 世紀の歴史があると言えるだろう.

Received 13 Jan. 2004 Accepted 16 June 2004
マガキの種苗（種ガキ）と一緒に北米西海岸に移入した貝 類は 10 種を超え, 中にはカキを食害するオウウヨウラク Ceratostoma inornatusなどの巻貝も見られた（荒川 1985）. 同様な過程で黒海へは種ガキに混じってアカニシRapana venosa が移入し定着している（荒川 1985）. イギリスやフ ランスでは 1960 年代から 70 年代にかけて日本から種がキ を大量に輸入し， ヨーロッパヒラガキOstrea edulis とポル トガルガキ Crassostrea angulata に代わって現在ではマガ キが定着しフランスのアルカッション湾などでは天然採苗 が行われている（大越ら 1992）。自然状態でも生活史を完 結しており，マガキはフランスやイギリス，イタリアなど ヨーロッパ各地に完全に定着したものと考えられる.オラ ンダでは, マガキの移入と定着・増加によってヨーロッパ イガイ Mytilus edulisなどの在来の貝類が減少し, さらに ミヤコドリHaematopus ostralegus あ減少したことや，イガ イベッドがカキ礁に置き換わりつつあることが報告されて いる (Wolfe \& Reise 2002). 
このように,これまでの海産貝類における移入は種ガキ やその固着基質である原盤（多くはカキまたはホ夕テガイ の貝殼）に固着または付着した生物がカキと一緒にわが国 から海孝渡ったものやムラサキイガイ Mytilus galloprovincialis の上うに船底などに付着して移動したものが多い。 ところが，近年それとは違った形で海を渡ってきた移入種 が日本国内で新たな問題を引き起こしている.

サキグロタマッメタ Euspira fortunei (Fig. 1) は砂地に生 息する夕マガイ科の貝食性卷具で, 二枚貝や卷貝の貝殼に 穿孔して軟体部老食べる，国内では三河湾以西に少数生息 し, 有明海では絶滅寸前（佐藤・田北 2000）之言われる希 少貝である。和田ら (1996)のWWFJのレポートで屯絶滅 寸前と評価されており, 瀬戸内海では山口県の数か所で少 数の採集記録（鳥越 1988; 和田弓 1996; 福田 2000）がある のみである。それが近年, それまで生息の報告がない東日 本や北日本からアサリ Ruditapes philippinarum を食害する 生物として報告され（酒井 2000; 大越 2002, 2003）問題に なっている. 2004 年 4 月には宮城県鳴瀬町の東名浜の観光 潮干狩り場でサキグロタマッメタによるアサリの大規模な 食害が明らかになり, 潮干狩りが解禁後数日で中止に追い 込まれるという事態が各種マスコミによって報じられた。 サキグロタマッメタはどこから来たのか，本研究ではサキ グロタマッメ夕の移入経路の解明とサキグロタマッメ夕以 外の非意四的移入生物の移入の現状を明らかにすることを 目的として, 潮干狩り用の観光漁場に撒くために外国から 輸入されたアサリに混入する生物の種やその数について検 討老行った。あわせて，国内におけるサキグロタマッメ夕 の分布状況老調查した.

\section{材料と方法}

\section{混入生物調査}

2002 年 3月～5 月にかけて宮城県石巻市万石浦の潮干狩 り用観光漁場に撒くために輸入され，陸送されてきたアサ リ十数トンの中から 1 回あたり約 100〜300 kg（全体の約 1/10の量)を取り出し, アサリの中に混入している生物を 同定，計数した。また，陸送業者扰よび漁業協同組合から の聞き取りにより, 輸入アサリの産地, 輸出港, 輸入港, 陸送経路などの情報を得るよう努めた。

\section{日本国内におけるサキグロタマツメタの生息調査}

国内の主要なアサリ生産地に㧍けるサキグロタマッメタ の生息状況を調查した。事前の聞き取りにより生息の可能 性のある地域は, (1) 直接出かけての採集, (2) 送付試料 の同定，(3) 送付写真の同定を行なった。本調査では調査 期間中にサキグロタマッメ夕生貝が複数個体採集された地 域のみを「生息確認地域」とし, 卵囊（砂茶碗）のみの採 集や写真情報掞よび手紙や電話, 電子メ一ルなどによる情 報は本研究では採用しなかった。

\section{結果と考察}

\section{アサリはどこからくるのか}

業者等による聞き取りの結果，アサリは中国の港から船 により輸出され, 山口県の下関港で検疫の後陸揚げされ, 大型トラックにより石巻市まで陸送されてくるものが多い ことがわかった。今回調查した中に韓国から輸出された之

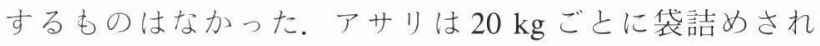
(Fig. 2), 大きさ別に大, 小に分けられていた，1つの袋に 入っているアサリが大小明らかに大きさに違いのある場合 ああったが，大（殻長 $4 \sim 5 \mathrm{~cm}$ 前後）といわれる袋の中に 小型のアサリ（多くは殼長 $4 \mathrm{~cm}$ 以下）が多数を占める場合 もあった，袋詰めは生産地または集積地（積出港）で行わ れているといい，少なくとも国内での陸送段階で詰め替え が行わ机ているという事実は確認できなかった。具体的な 生産地は, 北朝鮮之中国のあわせて数か所の情報があった が，具体的に生産（採集）場所を特定できる試料はなかっ た。集積地求よび積出港は中国遼寧省の金州や丹東という 情報がほとんよ゙であったことから，今回調查したアサリの 多くが中国から輸出されたものであると思わ机る。山本 (2000) に上ると流通ルートは (1) 北朝鮮加ら直接日本へ, （2）北朝鮮から中国国内の蓄養場を経て日本へ, など複数 あるという。今回の調査では, こ机以上の情報を得ること はできなかったが，少なくと屯調査したアサリは中国およ び（または）北朝鮮産ということができるだろう。

\section{混入する生物}

$20 \mathrm{~kg}$ の袋 (Fig. 2) の中から肉眼で確認できる大きさの 生物全個体を少しずつ白色のバットに広げ，アサリ以外の 生物を取り出した。また, 船上で袋を開け, 船に広げたむ の (Fig. 3)の中からもアサリ以外の生物を探してできるだ け取り出した (Fig. 4). 取り出した生物は生死を判別し, 種同定し, 袋ごとまたは船ごとに計数した。それ㧈らの結果 をTable 1 に示した.

混入していた生物は軟体動物門, 節足動物門, 触手動物 門に含まれる 22 種が同定された。未同定種を含めると種 は2 2 種以上に達するむのと思われる。軟体動物では, 腹足 類 10 種, 二枚貝類 9 種が同定された. 腹足類ではアサリな どを食害する夕マガイ科の生貝が 3 種含まれており，その 中にサキグロタマッメ夕も発見された。したがって, サキ グロタマッメタは輸入アサリ上ともに現在も外国から移入 していることが初めて明らかになった。採集された個体は ヤドカリ類に利用されていた貝殼などわずかなものを除 き，ほとんよ゙が生貝であったことから，通常はアサリと之 もにサキグロタマッメ夕をはじめ多数の生物が生きたまま 繰り返し観光漁場に放流されているもの上考えられる.

混入していた生物の種類や数は一様ではなく, 調査日時 や袋ごとに異なっていた。2002 年 3 月 24 日に調査した輸 

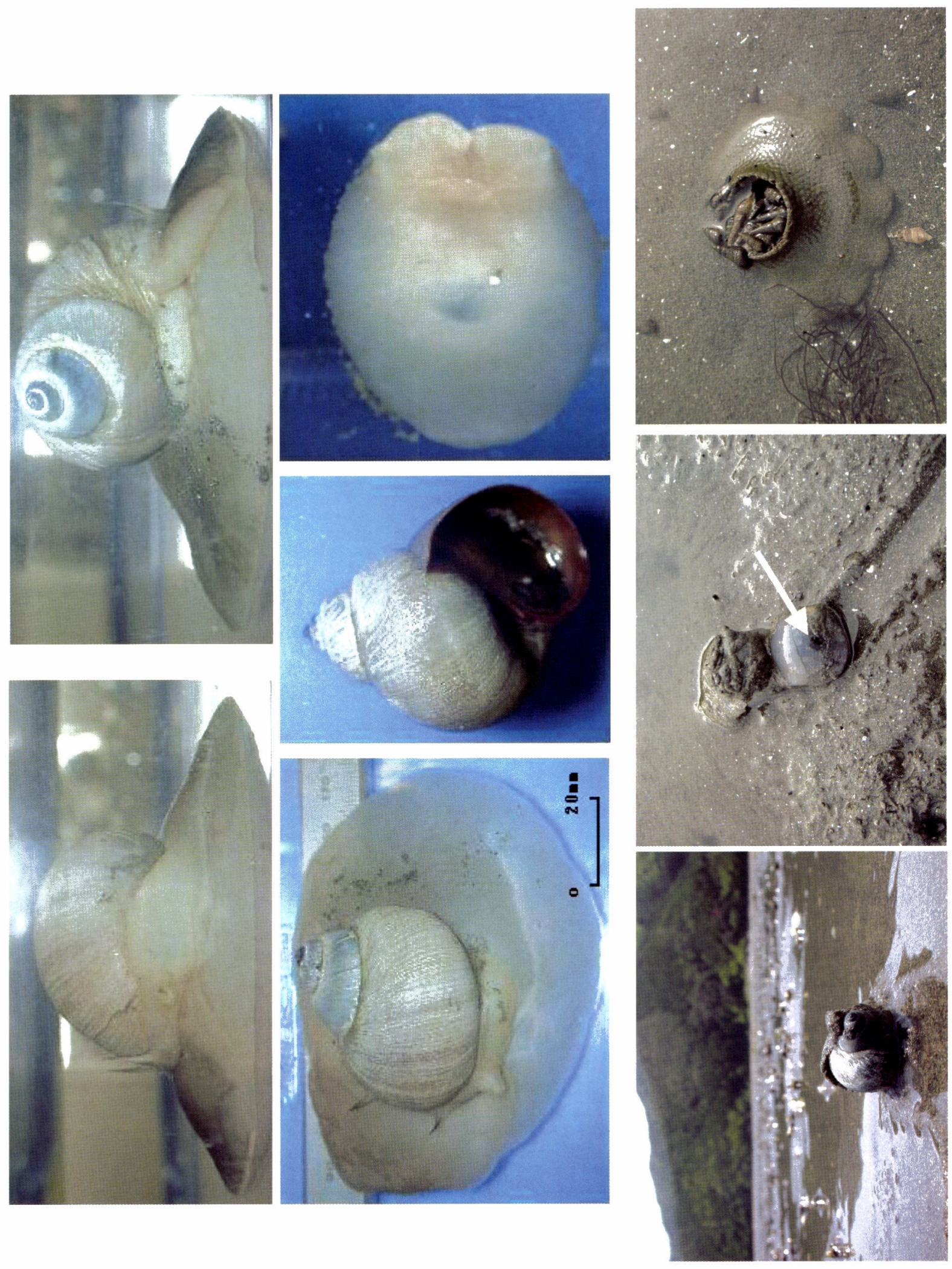

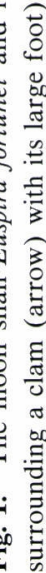




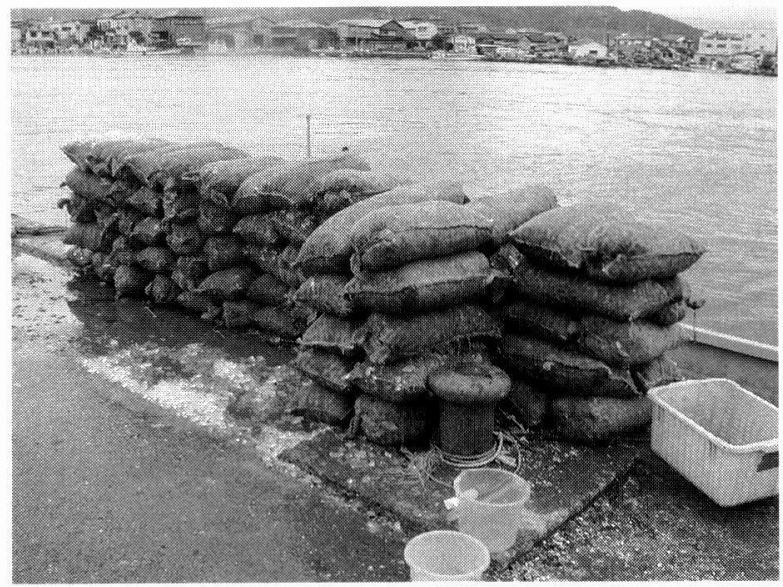

Fig. 2. Sacks filled with the clam Ruditapes philippinarum imported from China.

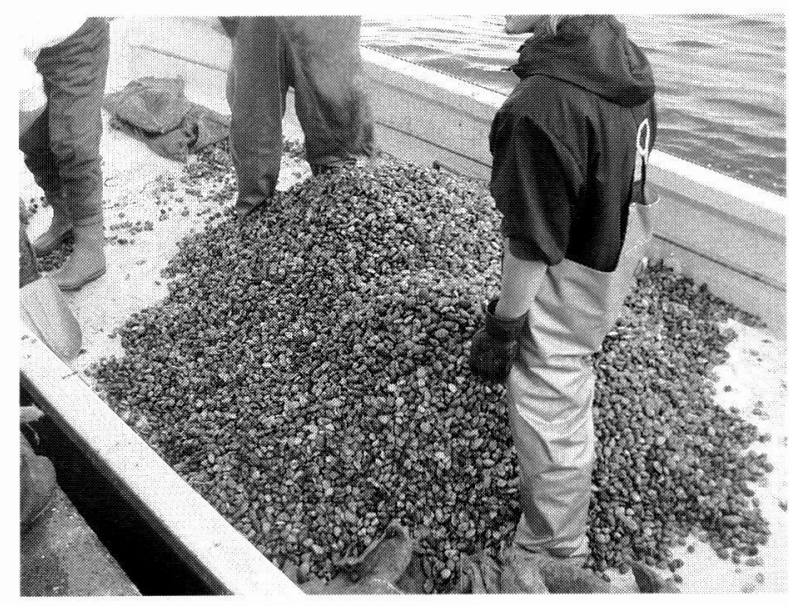

Fig. 3. Ship freighted with clams and alien species just before release.

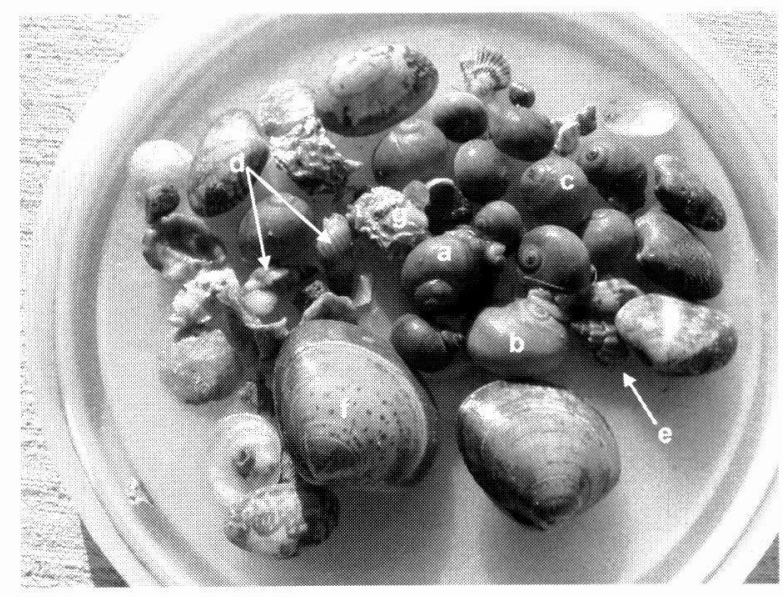

Fig. 4. Alien species collected from clam sacks. a, Euspira fortunei; b, Glossaulax didyma; c, Glossaulax reiniana; d, Varicinassa varicifera; e, Trigonostoma sp.; f, Meretrix pethechialis; g, Crassostrea gigas.

入アサリ 5 袋（約 $100 \mathrm{~kg}$ ）には, 二枚貝のサルボウ $S c a-$ pharca kagoshimensisのみが混入している袋が3袋あった が，その数は $1,10,56$ と大きく異なっており，1 袋に数百

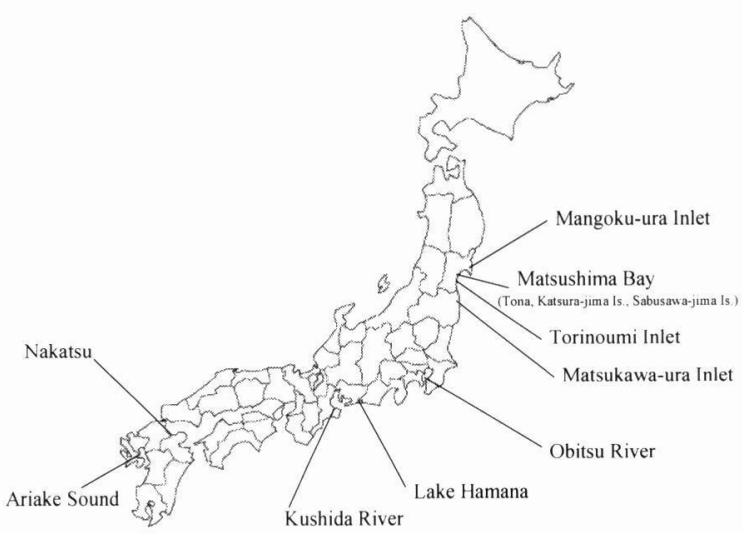

Fig. 5. Distribution of the mollusk-eating snail Euspira fortunei in Japanese waters.

$\mathrm{g}$ のサルボウの混入がある袋もあった， 4 月 12 日に陸送さ れてきた袋にはさまざまな生物が混入しており，とくにマ メコブシガニ Philyra pisum が多数見られた．5月 1 日のも のには腹足類, とくにタマガイ科の貝の混入が多く, 二枚 貝類は少なかった。 4 回の調査の中でアサリ以外の生物の 混入のない袋は一つもなく，混入生物は 1 袋あたり 1 個体 から最大で 56 個体もあった。調べた 25 袋， $500 \mathrm{~kg}$ には 266 個体の混入が認められたことから，計算上アサリ 100 $\mathrm{kg}$ あたり 50 個体前後の外来生物が紛れ込んでいることに なり，わが国全体のアサリ輸入量を考えるとおびただしい 数の外来生物が毎年生きたまま干潟に撒かれているものと 考えられる。調査日や袋ごとに混入する生物や量が違うこ とは，積出港は同じでも生産地が異なること，あるいは生 産地によってアサリ選別の精度が異なるなどが考えられ る.

\section{日本国内におけるサキグロタマツメタの分布}

サキグロタマツメタの生息が確認された場所を Fig. 5 に 示した. 北から宮城県の万石浦, 東名を含む松島湾内 3 か 所, 鳥の海, 福島県の松川浦, 千葉県の小梖川河口, 静岡 県の浜名湖，三重県櫛田川河口，大分県の中津干潟，有明 海であった。有明海以外はすべて生貝を採集して持ち帰っ た. 岩崎ら (2004) のアンケート調査では, 標本や生貝の確 認を行っていない場合もあるが，上記以外の地域からもサ キグロタマッメタの生息が報告されており，さらに広範囲 に生息しているものと推定される. 聞き取り調査の結果, 有明海でサキグロタマッメタの生息が確認された場所以外 では，過去あるいは現在屯輸入アサリの放流が行われてい る地域であることがわかった。 サキグロタマッメタは，こ れまで三河湾以西に生息しているとされているので，少な くと屯, 静岡県, 千葉県, 福島県, 宮城県で発見されたサ キグロタマッメタは輸入アサリに混入してわが国に入った 外来移入種であると考えられる。また，三重県や大分県で む輸入アサリを放流していることから，少なくとむ発見さ れたサキグロタマツメタの一部あるいは多くが外来移入種 


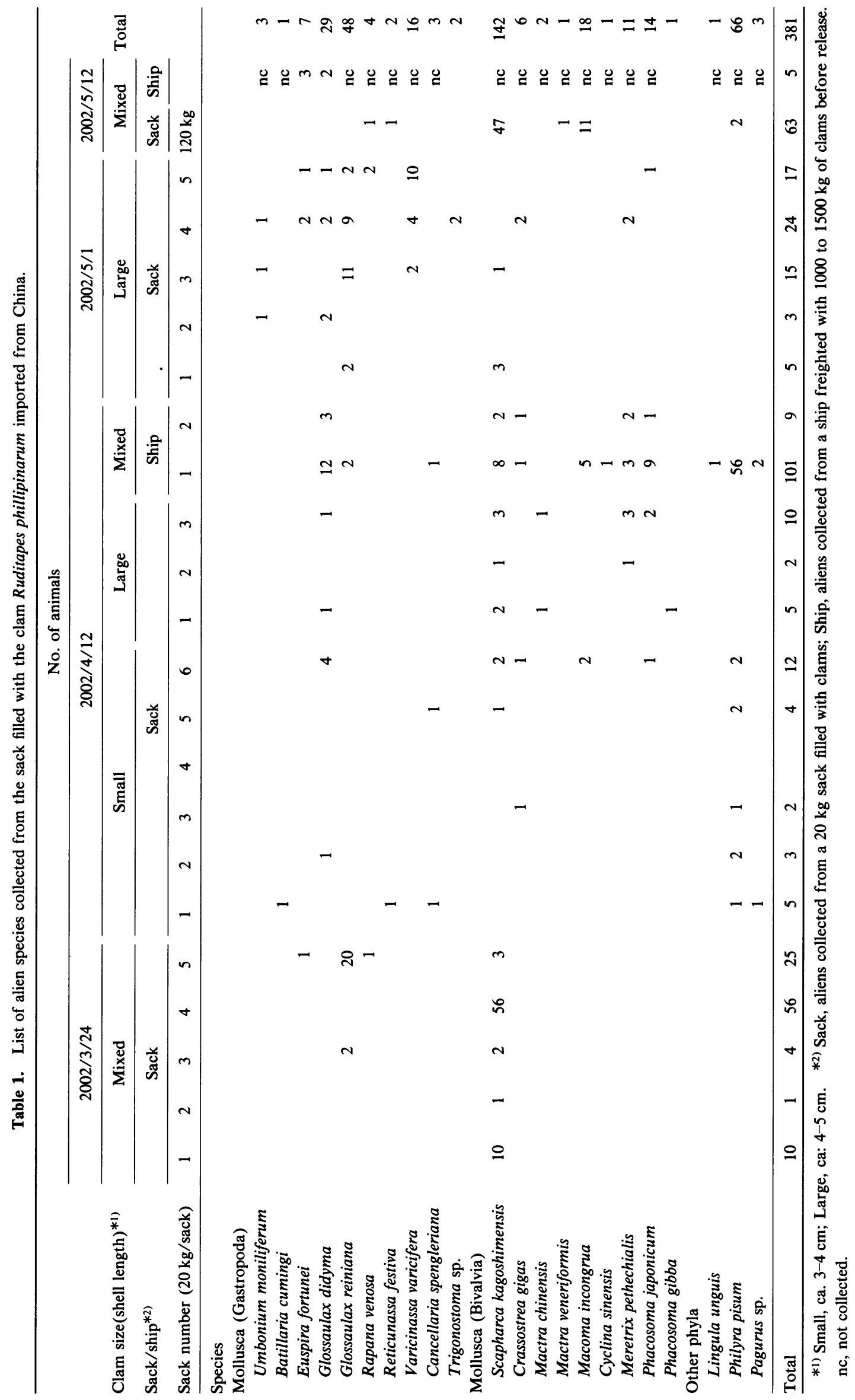




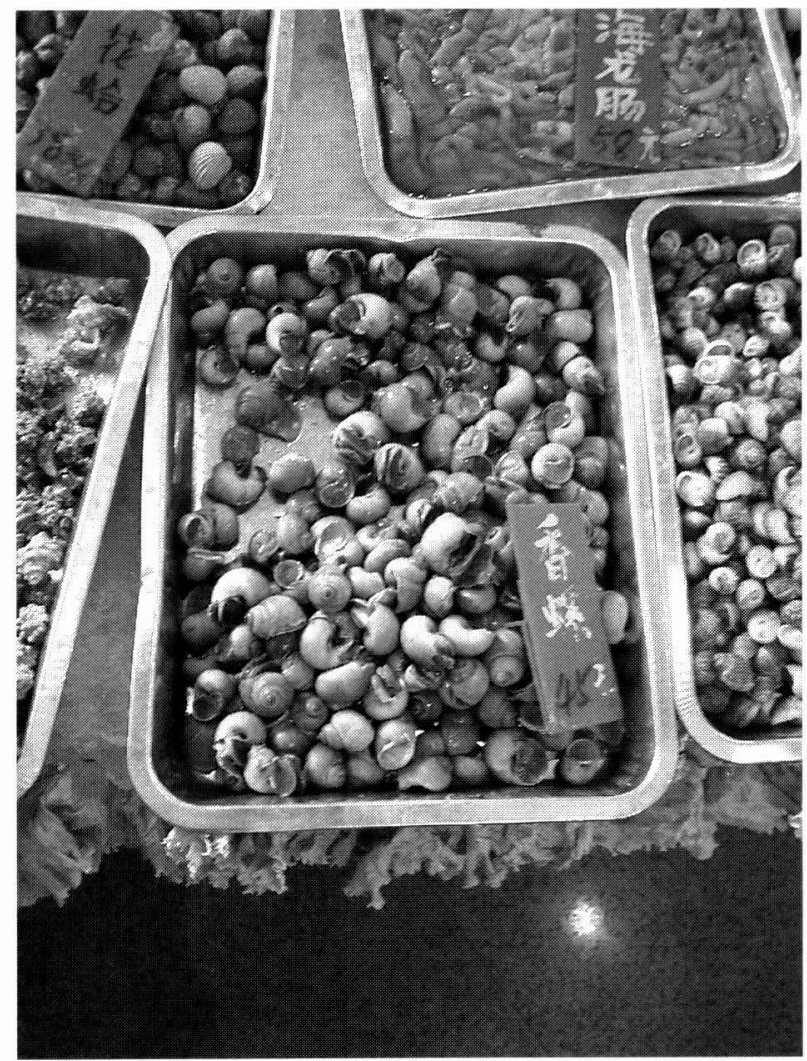

Fig. 6. Euspira fortunei at a Chinese restaurant in October, 2003, in China (courtesy of $\mathrm{K}$. Tanaka)

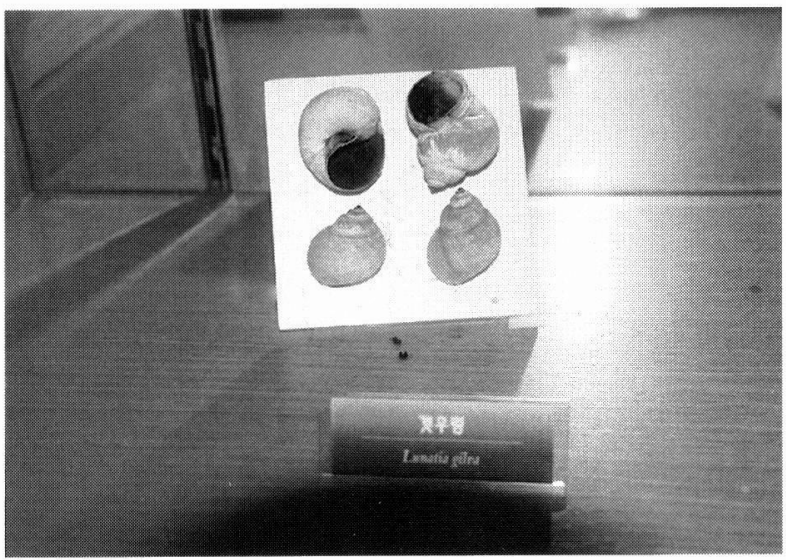

Fig. 7. Specimens of Euspira fortunei at the museum of Ganghwa Island near Seoul in August, 2003 (courtesy of K. Satake).

\section{である可能性が高い.}

\section{サキグロタマツメタの定着}

中国や韓国ではサキグロタマッメタは図鑑やフィールド ガイドなどに図版や写真とともに揭載されており，一般に あ知られた貝であることがうかがえる。中国ではレストラ ンで食材として提供されており（Fig. 6; 田中私信）, 斉ら (1989) には黄渤海の 27 か所から標本が採集されたとの記 述があり，そ扎以外でも「向南可分布到東海，比外，朝鮮 和日本他有分布」としている。他にも南は広東沿岸まで分 布（趙ら 1982），中国南北沿岸に広く分布（王 1988）など
があり中国沿岸には広く分布しているものと考えられる。 韓国では図鑑（権ら 1993）や複数のフィールドガイド（明 1999, 2000, 2001, 2002）に写真入りで掲載されており，ソ ウル近郊の江華島の干潟体験施設には, 学名は誤っている がサキグロタマッメタの標本が展示されている（Fig. 7; 佐 竹私信)。セマングム地域（佐藤ら 2003）や南部の慶尚南 道（溝口・逸見 2003; 山下 2003）でも生息が確認されてお り韓国では北部から南部まで分布しているものと考えられ る. 北朝鮮に関してはこれまで生息に関する情報は得てい ないが，少なくとも韓国から中国の沿岸には広く生息して いる種であると考えられる。

一方，国内では主に西日本に生息し，その生息数も少な いものと思われる。これまで, タマガイ科ではッメタガイ Glossaulax didyma については古くから報告があり, ッメ夕 ガイによるアサリの食害は近年熊本県や愛知県, 千葉県な どの主要なアサリの生産地域で報告されている（平山ら 1996; 瀬川・服部 1997; 柴田・河西 1997)。しかし, サキグ ロタマッメタについては宮城県万石浦で問題になる以前は 全く報告がない，網尾 (1955) は西日本各地之北海道から タマガイ科 7 種の卵囊（砂茶碗）を採集しそれらの形態と 初期発生について記載しているが，その中にもサキグロ夕 マッメタに関する記載はない. Torigoe (1989) の歯舌の形 態に関する記載などはあるが，生物学的にも水産サイドで もこれまでほとんど研究されてこなかった貝と言える。東 日本や北日本には生息の報告がないサキグロタマッメタが 宮城県の万石浦では数 $\mathrm{mm}$ の小型個体加ら $50 \mathrm{~mm}$ 以上の 大型個体まで生息が確認されており（大越 2003）, 卵囊も 多数発見されていることから，すでに定着して再生産を 行っている屯のと考えられる。輸入アサリに混じって移入 したサキグロタマッメタの中には $10 \mathrm{~mm}$ 以下の個体は発 見されていない，このことからも，万石浦で発見された小 型個体は万石浦で発生したすのと考えられる。

サキグロタマッメ夕は浜名湖では 1980 年代後半（後藤 私信), 千葉の小櫃川河口では 1990 年代の前半（山川 私 信）に発見されており，宮城県万石浦では 1999 年ごろから 浦の奥部から食害が報告され始め（酒井 2000）, 現在は湾 内全域で発見されている。浜名湖ではアサリ生貝の輸入は 1980 年代はじめから始まり 1993 年までは年々増加傾向に あり，その後横ばいから漸減之なっている（山本 2000）が, アサリの輸入が始まり增加していった時期にサキグロタマ ッメタが発見されている。 また，サキグロタマッメタ発見 の時期が東日本から北日本にかけて少しずつ後ろにずれて いるようにみえる。近年は少なくなったが，以前はアサリ 以外の生物（これらを総称して現場では「雑貝」と呼ばれ ている）の混入が多く, 輸入業者が輸出元にクレームをつ けるということああったとの情報ああった。わが国から種 ガキを輸出する場合は, 海に垂下した原盤にマガキの幼生 を付着させる方法で種ガキを採っており，マガキだけを採 集するために幼生の出現や付着時期を推定して原盤の投入 
が行われている，一方，アサリは熊手やじょれん，けた網 などによる採集が行われており，網籠の目合い，つまり大 きさで採集生物を分けており，目合い以上の大きさの他の 生物む一緒に採集される。現地でアサリの選別がきちんと 行われないまま袋詰めにされた場合，アサリ以外の生物は どんどん移入してくることになる. Table 1 ではアサリと 大きさの異なるシナハマグリMeretrix pethechialis（Fig. 4 の 2 個体の大型の二枚貝) や形も明らかに異なり移動能力 あ高いマメコブシガニなどあ多数見つかっており, 生産地 での選別が不十分であることがうかがえる．濡れた麻袋に 収容し短期間で（聞き取りの一例では 2002 年 4 月 11 日午 前, 中国の港を出て 17 時に下関着, 19 時すぎ陸送で下関 発, 翌 12 日午前, 宮城県石巻市に到着) 運ばれるため途中 で死亡する個体す少ないものと考えられる。「不十分な選 別, 迅速な運搬, 選別なしの放流」の長年の結果がアサリ 輸入に伴って多くの生物が移入した原因と考えられる.

今回の調査でタマガイ科の貝の混入は，サキグロタマッ メタ, ツメタガイ，ハナッメタGlossaulax reiniana の 3 種 が見られたが，その中でサキグロタマッメタの数が一番少 なかった。しかし，万石浦にはサキグロタマッメタだけが 多数生息している，その理由は明らかではない，今回はた またま混入が少なかったのかむしれない，一方，2002 年 3 月 31 日から万石浦の観光漁場では「アサリの天敵サキグ ロタマッメタガイ」という看板を立てて入漁者にアサリと ともに採集したタマガイ科の貝の陸揚げを依頼している. その結果, 陸揚げされた貝は 5 月 15 日までに 1433 個体に なったが，それらは全個体サキグロタマッメタであった （大越 2003）。この期間, 観光漁場には輸入アサリとともに サキグロタマッメタ, ッメタガイ，八ナッメタの 3 種の生 貝が放流されたはずである，すでにサキグロタマッメ夕は 定着しているので採集数が多いと考えられるが，ツメタガ イとハナッメ夕の生貝が 1 個体も採集されなかったこと は, 放流後に死亡した可能性を示唆する. 万石浦の外海之 つながる水路より外側ではツメタガイの生息が以前より確 認されており, 宮城県水産研究開発センターの桁網による 調査でも大型のッメタガイが石巻湾で採集されている（宮 城県 未発表)。しかし，万石浦内ではこれまでほとんど生 貝の採集記録がなく, 著者らが調查を開始した 2001 年 9 月から 2003 年 12 月までの間では観光漁場の調查海域で 2 個体（サキグロタマッメ夕は数千個体）のみ採集されてい る. 千葉県の小櫃川河口ではサキグロタマッメタは河口側 に, ッメタガイはそれより海側で採集される（山川私信； 大越未発表) ことが多く, 両者の生息環境は異なることが 推定される.このことが約 $100 \mathrm{~m}$ の水路だけで海とつな がっている袋状の内湾である万石浦にサキグロタマッメ夕 が定着した一因かむしれない。八ナッメ夕は国内では房総 半島以南に生息しており（斉藤 2000）東北や北海道には生 息していないことから万石浦での生息は困難なのかもしれ ない，ところがサキグロタマッメタは国内では三河湾以西
に生息し，それより東北では生息が見られないにもかかわ らず万石浦ではすでに定着しているすのと考えられる。 そ の理由あ不明である。 ただ，中国におけるアサリの主な産 地（山本 2000）から北朝鮮をはさんで韓国のソウル近郊の 干潟までの緯度が, 日本では東北地方, 太平洋側では岩手 県から宮城県の緯度とほぼ一致している点が注目される。 サキグロタマッメ夕は有明海では準特産種とされており, 有明海に生息する特産種之準特産種の多くが大陸沿岸性遺 存種とされている（佐藤・田北 2000）。それらは 1 万年以 上前の対馬海峡の成立と日本列島の分断とともに，大陸の 大きな個体群から日本の小さな個体群が分断されて現在に 至っている（佐藤・田北 2000）と考えられている. 分断の 過程では生息環境的には好適であっても地理的にみて東北 日本には分布し得なかったサキグロタマッメタが, 近年の 人為的移入の結果, 現在の原産地と類似の環境を得て定着 したという可能性も考えられる. マガキがフランスやイギ リス, アメリカの内湾で定着していることや黒海のアカニ シの定着の先例がそのことを示唆している. 今後, 中国や 韓国の原産地での生息環境調査やそれら個体群との遺伝的 類縁関係を検討することによりこれらの点を明らかにして いきたい.

\section{非意図的移入種，サイレント・エイリアン}

サキグロタマッメタは水産重要種であるアサリの食害生 物であったために問題か顕在化した。.しかし，今回の調査 でサキグロタマッメ夕以外にも多数の生物がアサリに混 じって移入していることが明らかになった，その中には国 内では報告がない Phacosoma gibba をはじめ, 希少種とさ れているウネハナムシロVaricinassa varicifera やミドリ シャミセンガイ Lingula unguisなどあ含まれている，その 中で万石浦には生息していなかったシナハマグリの生貝が 観光漁場で時々採集されている（大越 2003）。シナハマグ リは食害生物ではなく，しかむ食用として中国から輸入さ れている水産重要種であり，アサリととあにスーパーの店 頭にも並び一般にもなじみが深い. 店頭での名称も「八マ グリ」となっているが，ハマグリMeretrix lusoria やチョウ センハマグリ Meretrix lamarckii と区別しない場合でも農 林物資の規格化及び品質表示の適正化に関する法律 (JAS 法）違反にはなっていない。このように，シナハマグリは 移入種であってもサキグロタマッメタとは異なり, 水産の 現場ではほとんど問題になっていない，潮干狩り用に小型 のシナハマグリを干潟に放流しているところあある（小菅 2002）という. 国内ではすでにシナハマグリが定着したと 考えられる場所むあり, 八マグリとの交雑も懸念されてい る（小菅 2002），万石浦でシナ八マグリが定着する可能性 は不明だが，もともと万石浦には八マグリは分布しておら ず，仮に定着した場合，漁業者はそれらを漁業対象あるい は潮干狩り対象生物として「好意的に」認識するかすしれ ない。 

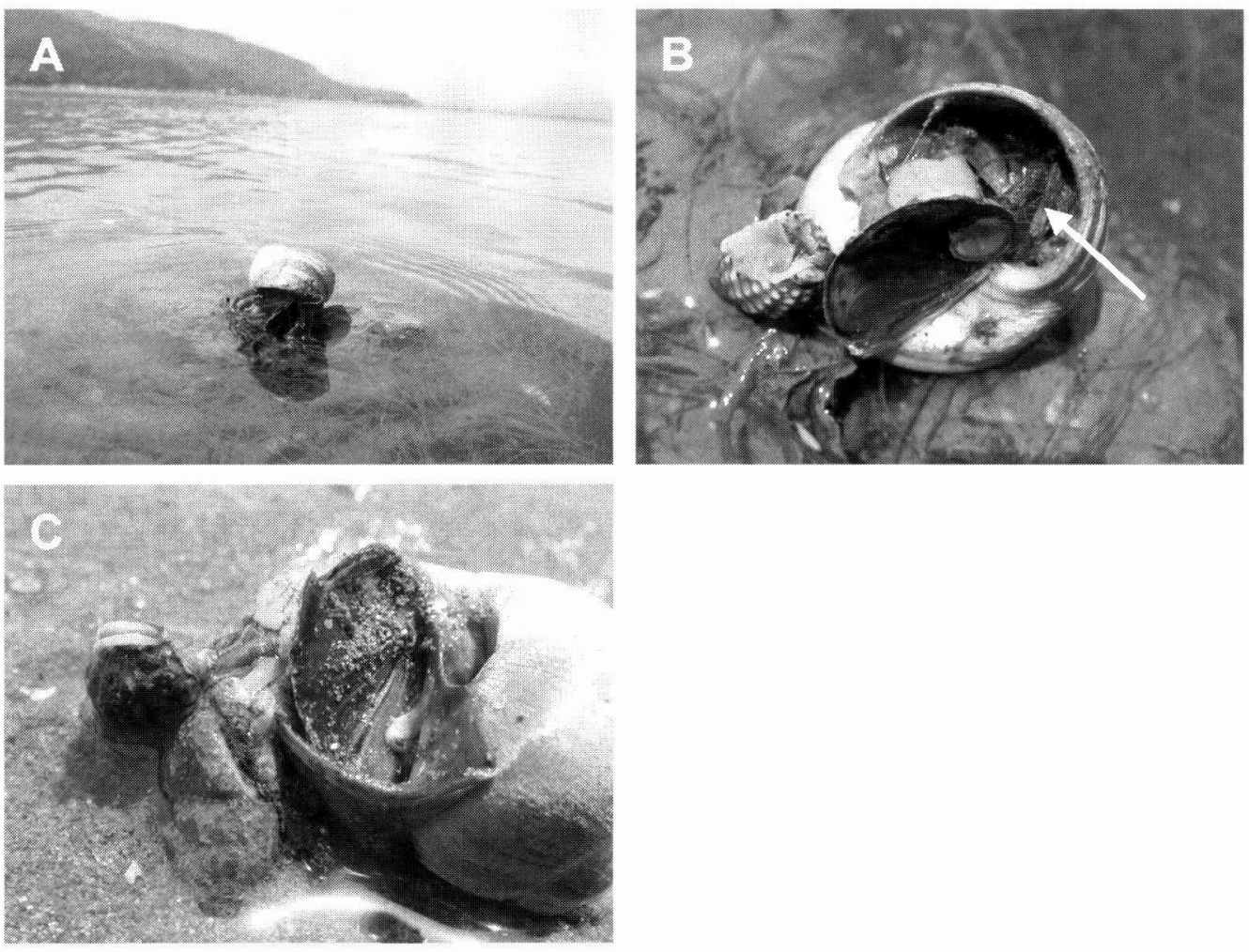

Fig. 8. Pagurus sp. in a shell of dead Euspira fortunei (A, arrow in B) and scavenger Reticunassa festiva (B, C) feeding on dead Euspira fortunei in Mangoku-ura Inlet, Miyagi, Japan.

一方, 混入生物の中でオキシジミ Cyclina sinensis やホソ ウミニナ Batillaria cumingi, マメコブシガニは万石浦の在 来種であり, 現在万石浦に多数生息している. アカニシも 少数の生息がみられる。 サキグロタマッメタやシナハマグ リのように，これまで生息が知られていない種では，新た に採集された個体は移入種であることがわかる。しかし， オキシジミやンリゥニナは在来の個体加移入個体かの区 別がつかない，すでに同種が生息している環境であること 加移入個体も生き残る可能性が高く，しかむ容易に交雑 するだろう。その結果, 在来種と移入種の遺伝的交流が起 り，これまでの地域個体群とは異なった遺伝子組成をむつ 個体群が徐々にあるいは急激に形成されていくことが考え られる，その先が個体群の増大につながるのか消滅に向か うのか，あるいは何む起こらないように見えるのかはわか らないが, 干潟生態系を構成する主要な複数の種でこれら のことが起こることは, 干潟生態系全体に影響を及ぼす可 能性があり, 看過できない問題である. 近年の環境省の干 潟調査やミトコンドリア DNA 等を用いた種分化の研究の 結果をあ大きく歪めることになるだろう。

万石浦に生息する大型の巻貝はアカニシのみで，その数 は少ない. スガイ Turbo coronatus coreensisやイシダタミ Monodonta labio あ少数であり, ヤドカリ類の多くはこれま ではスガイやイシダタミの死款を利用していた。 ところが 近年, 款高 3 5 cm のサキグロタマッメタの死凯があちこ ちで見つかるようになり, その多くをヤドカリ類が利用し
ているのを目にする. 小型のイシダタミの貝殼から死んで 間屯ない軟体部が残っているサキグロタマッメ夕の貝款に 交換しょうとしているヤドカリ類も見つかっている (Fig. 8).これまで中型の巻貝の貝殼の供給がほとんどなかった 万石浦にサキグロタマッメタが移入したことにより, 今後 多数の貝殼が供給されれば, ヤドカリ類各種の個体群の変 動に影響を及ぼす可能性も考えられる。このような視点か ら屯サキグロタマッメ夕の移入の影響を考えなけ机ばなら ない，アサリに寄生して万石浦に移入したと考えられる力 クレガニ類（大越 2003）についても同様である.

このように, シナハマグリのような新たな漁業対象種の 出現や在来種之同種の移入個体や寄生種の移入は表面上は 問題にならず, 移入の実態や在来個体群の変化を捉えるこ と屯非常に難しい。著者は「国外抢よび国内起源の移入種 であっても漁獲対象種や食害生物ではないために，その移 入実態や定着, その後の同種あるいは異種の在来生物に対 する影響が掴みにくい種」を,「静かな移入種：サイレン ト・エイリアン (silent alien)」と称する. サイレント・エ イリアンは知ら奴間に侵入し, しかも駆除の対象とならな い、しかし，これらサイレント・エイリアンの移入はサキ グロタマッメ夕のような食害生物 1 種の移入よりはるかに 大きな問題を内包しているものと考えられる，非意図的移 入種, そして移入種かどうかの判断もつきにくいサイレン ト・エイリアンについては現在国内ではほとんど検討がな されていない，国レベルでの緊急な調査と移入を阻止する 
対策が必要であると考えられる.

謝 辞：調査にご協力いただいた石巻湾漁業協同組合の阿部卓 也氏, 千葉県水産研究センター富津研究所の鳥羽光晴博士, 静岡 県水産試験場浜名湖分場の後藤裕康氏, 瀬戸内海区水産研究所の 浜口昌巳博士, 東京海洋大学の山川紘博士, 石巻専修大学大越研 究室の大学院生と 4 年生に感謝いたします。また，中国や韓国に おけるサキグロタマッメタの情報と写真図版の提供をいただいた 志津川町自然環境活用センターの田中克彦博士, 国立環境研究所 の佐竹潔博士, 岡山大学の福田宏博士, 東北大学の佐藤慎一博士, 種同定や原産地推定にご協力いただいた海洋研究開発機構の奥谷 喬司博士にお礼申し上げます，また，英文校閲をしていただいた Mark Grygier 博士，匿名のレビュアーの有益なコメントに感謝い たします。

\section{引用文献}

網尾 勝 1955. 邦産玉貝科 7 種の卵塊及び躬化幼生に就いて。農 林省水産講習所研究報告, 5: 49-70.

荒川好満 1985. 食用カキ一移植にともなう付着動物の侵入．沖山 宗雄・鈴木克美(編)，日本の海洋生物一侵略と摚乱の生態学, 東海大学出版会, 東京, pp. 69-78.

Baeck, Y. H. (백용해) 1999. 살아있는 갯벌 이야기(生きている 干潟の物語）창조모안(創造文化社)，Seoul, 246 pp. (In Korean)

Baeck, Y. H. (백용해) 2000. 갯벌탐사지침서 갯벌 (干潟探査指針 書干潟) 창조모안(創造文化社), Seoul, 278 pp. (in Korean)

Baeck, Y. H. (백용해) 2001. 시원한여행갯벌속으로 (1) 창조모안(創 造文化社)，Seoul, 213 pp. (in Korean)

Baeck, Y. H. (백용해) 2002. 시원한여행 갯벌속으로(2) 창조모안(創 造文化社)，Seoul, 216 pp. (in Korean)

趙 汝翼・程 済民・趙 大東 1982. 大連海産軟体動物誌. 海洋 出版社, 北京, $3+167$ pp. +22 pls. (in Chinese)

平山 泉・石田宏一・鳥羽瀬憲久・平田 満 1996. 緑川河口域 で見られたッメタガイによるアサリの食害. 熊本県水産研究セ ン夕一研究報告, 3: 12-17.

福田 宏 2000. 巻貝類 I一総論. 佐藤正典(編), 有明海の生き物 たち, 海游舎, 東京, pp. 100-137.

権 伍吉・朴 甲萬・李 俊相 1993. 原色韓国貝類図鑑. Academy Publishing Company, Seoul, 446 pp. (in Korean)

岩崎敬二・不村妙子・木下今日子・山口寿之・西川輝昭・西栄二 郎・山西良平・林 育夫 - 大越健嗣・小营丈治・鈴木孝男・逸 見泰久・風呂田利夫・向井 宏 2004. 日本における海産生物 の人為的移入と分散：日本ベントス学会自然環境保全委員会に よるアンケート調査の結果から. 日本ベントス学会誌，59: 2244.

小营丈治 2002. シナ八マグリ〜在来種ハマグリ衰退との関係 は? 日本生態学会(編), 外来種ハンドブック, 地人書館, 東京, p. 190.
溝口幸一郎・逸見泰久 2003. 韓国光陽市および麗水市周辺の干 潟における底生生物相 ベントス調査 2 班報告書 (定性調查). 日韓共同干潟調查 2001 年度報告書, pp. 31-38.

王 如才 1988. 中国水生貝類原色図鑑. 析江科学技術出版社, 4+ $3+5+10+255$ pp. (in Chinese with English summary)

大越健嗣 2002. 貝殼は記憶する. 自然保護, 469: 38-41.

大越健嗣 2003. サキグロタマッメタ一絶滅危惧種は食害生物. う みうし通信, 39: 2-4.

大越健嗣・菅原義雄・大越和加 1992. 水産增養殖生産地域にお ける観光・リゾート開発の現状と問題点一フランス, アルカッ ション湾との比較研究—. Proceedings of the Techno-Ocean '92 Symposium, pp. 727-734.

斎藤 寛 2000. 夕マガイ科. 奥谷喬司(編), 日本近海産貝類図鑑, 東海大学出版会, 東京, pp. 250-267.

斉 鐘彦・馬 秀同 - 王 禎瑞 - 林 光宇 - 徐 鳳山・董 正 之・李 鳳美・呂 端貨 1989. 黄渤海的軟体動物. 農業出版 社, 北京, 309 pp. +13 pls. (in Chinese)

酒井敬一 2000. 万石浦アサリ漁場におけるサキグロタマツメ夕 ガイの食害について. 宮城県水産研究開発センター研究報告, 16: 109-111.

佐藤正典 - 田北 徹 2000. 有明海の生物相と環境. 佐藤正典 (編), 有明海の生きものたち, 海游舎, 東京, pp. 10-35.

佐藤慎一・山下博由・久保 監 2003. 韓国セマングム地域の干 拓防潮堤建設に伴う干潟底生生物群集の時間的变化. 日韓共同 干潟調查 2001 年度報告書, pp. 62-75.

瀬川直治・服部克也 1997. 伊勢湾小鈴谷干潟におけるッメタガ イによるアサリの食害. 愛知県水産試験場研究報告, 4: 41-48.

柴田輝和・河西伸治 1997. 東京湾盤洲干潟之富津干潟のアサリ 漁場におけるッメタガイの大量発生と駆除方法. 千葉県水産試 験場研究報告, 55: 25-31.

鳥越兼治 1988. 山口県岥波のサキグロタマッメタガイ。ちりぼた h, 19: 69-70.

Torigoe, K. 1989. Radula of Lunatia fortunei (Reeve, 1865). Venus, 48: 46-49.

和田恵次・西平守孝 - 風呂田利夫 - 野島 哲 - 山西良平・西川輝 昭・五嶋聖治・鈴木孝男・加藤 真・島村堅正・福田 宏 1996. 日本における干潟海岸とそこに生息する底生生物の現 状. WWF Japan Science Report, 3: 1-182.

Wolfe, W. J. and K. Reise 2002. Oyster imports as a vector for the introduction of alien species into northern and western European coastal waters. In Invasive Aquatic Species of Europe. Distribution, Impacts and Management, Leppäkoski, E., S. Gollash and S. Olenin (eds.), Kluwer Academic Publishers, Dordrecht, pp. 193-205.

山本茂雄 2000. アサリ稚貝放流事業の問題点, 第 9 回浜名湖をめ ぐる研究者の会講演要旨集, pp. 27-32.

山下博由 2003. 慶尚南道南海郡（第五次日韓共同干潟調査）にお ける軟体動物・腕足動物の地点別定性調査デー夕. 日韓共同干 潟調査 2001 年度報告書, pp. 39-57. 